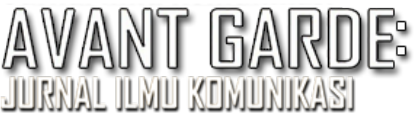

\title{
Public Relations Activities of State Universities Based on The Excellence Theory
}

\author{
Rachmat Kriyantono \\ e-mail: rachmat_kr@ub.ac.id \\ School of Communication, Brawijaya University, Indonesia
}

Submitted: 30 October 2019 Revised: 25 November 2019 Accepted: 19 December 2019

\begin{abstract}
This study aims to describe the public relations activities of state universities in carrying out their functions. The standard of activity is based on the Theory of Excellence. The quality of public relations activities is very important related in the era of public information openness which requires universities to conduct public services well as part of good governance. Theory of Excellence is the most dominating theory of public relations studies in the world as a normative standard for good public relations practice. This study uses a survey method by distributing questionnaires to 59 public relations practitioners of state universities. The research also interviews three practitioners to detail data from questionnaires. This research results in finding that the principles of Excellence Theory have begun to be adopted by public relations practitioners. Symmetrical twoway communication strategies have also been found although there is still more focus on the external public. Other findings indicated that PR activities have been included as part of management activities and dominant coalition in state universities. This research is expected to contribute to the development of public relations studies in the Indonesian context. The success of increasing service professionalism, increasing active community participation, and service openness very much depends on the communication and information functions applied.
\end{abstract}

Keywords: Excellence Theory, Good Governance, Public Relations, State University

\section{Aktivitas Hubungan Masyarakat Universitas Negeri Berdasarkan Teori}

\begin{abstract}
Abstrak
Penelitian ini bertujuan untuk mendeskripsikan kegiatan humas universitas negeri dalam menjalankan fungsinya. Standar kegiatan didasarkan pada Teori Eccellence. Kualitas kegiatan hubungan masyarakat sangat penting terkait era keterbukaan informasi publik yang mengharuskan perguruan tinggi untuk melakukan layanan publik sebagai bagian dari tata kelola yang baik. Teori Excellence adalah teori studi hubungan masyarakat yang paling mendominasi di dunia sebagai standar normatif untuk praktik hubungan masyarakat yang baik. Penelitian ini menggunakan metode survei dengan membagikan kuesioner kepada 59 praktisi humas dari universitas negeri. Penelitian ini juga mewawancarai tiga praktisi untuk merinci data dari kuesioner. Penelitian ini menghasilkan temuan bahwa prinsip-prinsip Teori Excellence telah mulai diadopsi oleh praktisi hubungan masyarakat. Strategi komunikasi dua arah yang simetris juga telah ditemukan walaupun masih ada lebih banyak fokus pada publik eksternal. Temuan lain menunjukkan bahwa kegiatan hubungan masyarakat telah dimasukkan sebagai bagian dari kegiatan manajemen dan koalisi dominan di universitas negeri. Penelitian ini diharapkan dapat berkontribusi pada pengembangan studi hubungan masyarakat dalam konteks Indonesia. Keberhasilan meningkatkan profesionalisme layanan, meningkatkan partisipasi masyarakat aktif, dan keterbukaan layanan sangat tergantung pada fungsi komunikasi dan informasi yang diterapkan.
\end{abstract}

Kata Kunci: Hubungan Masyarakat, Tata Kelola Pemerintahan, Teori Excellence, Universitas Negeri 


\section{INTRODUCTION}

Transparency or public information openness is a condition for the realization of good governance (Fairbanks, Polwman $\&$ Rawlins, 2007). The researcher believes that good governance also applies to state universities as a government institution. The principles of good governance that include openness, accessibility, accountability, and professionalism in delivery of public services really require an open communication system (Kriyantono, 2015). The principles hand in hand with the public character of government institutions, which mostly come from millennial groups that have the nature of needing fast, always using technology, like to share experiences, and being critical of social phenomena (Wijayanti, 2018).

Openness will only occur if the communication system allows higher education affairs to be managed transparently and public access is participatory (Purdy, Idriss, Ahern, 2017). Some research has been conducted and shows the link between public information disclosure and the establishment of good governance. Then, there are also studies that link it with the application of information technology, such as Qureshi (2014) who found that the diffusion of information through the diffusion of the internet has reduced the voice of accountability and corruption in the government; the application of communication technology that enables openness and participation has increased transparency and built public trust (Ohemeng \& Adarkwa, 2014).

Schenkelaars and Ahmad (2004) found that access to public information provided by the Arab Government could disseminate information to the public as an effort to improve the services of the Arab Government to the community because it had involved the community in the public policy process. Schenkelaars and Ahmad's (2004) research is also strengthened by Anyanwu, Akanwa \& Ossai's (2013) research on transparency in Nigeria which has been regulated by establishing the Bill on Freedom of Information Bill, as part of national development. This law has stimulated a form of transparency that has a social and economic impact on Nigerian society.

In Indonesia, democratization is increasingly developing with the formulation of Law No. 14 of 2008 on Public Information Openness (Kriyantono, Destrity, Amrullah, \& Rakhmawati, 2017; Suharyanti, Widiastuti \& Kania, 2012). The rule of law is very important to be the foundation of public information disclosure, as written by Dikopoulo \& Mihiosis (2012, p. 135) that "transparency exists when all actions and decisions are prepared, legalized, and implemented through the rule of law, through a democratic process with due regard for rights human rights."

Public services, based on Law no $25 / 2009$, are the main tasks of state institutions, including tertiary institutions. To ensure public services can be realized, it is absolutely necessary to meet the principles of service set out in Law No. 25 of 2009, in the form of professionalism of the organizer, participatory, openness, and accountability of the service process. Therefore, governance of communication that is able to provide accessibility and access to information that is friendly to 
access, is a necessity in the accountability architecture of government institutions. Accessibility of information as part of communication policy is an important factor in the relationship between the delivery of educational services and their performance indicators.

The success of increasing service professionalism, increasing active community participation, and service openness very much depends on the communication and information functions applied. The main purpose of public information disclosure in each country is to ensure that public institutions will be more accountable and credible by providing information and documents according to public demand (Retnowati, 2012). Openness of public information is a means to optimize the administration of the state, the role and performance of public bodies that have an impact on the public interest (Pradipta, 2009). Openness of public information is important to realize good governance, because closed government is prone to deviations and misuse (Prabowo, 2004).

In the academic literature it is stated that public relations has the function of carrying out information services, namely "management of communication between organizations and their publics" (Grunig \& Hunt, 1984). Specifically, excellence theory underlines that one of the standard principles of public relations is a two-way symmetrical nature in establishing public relations (symmetrical models) (Kriyantono, 2017). Academic opinion above is also written in the regulations on public relations from the government. Regulation of the Minister of Administrative Reforms Bureaucratic Reform No 30 and 31 of 2011 states that
Public Relations of the government is management in the field of information and communication in government institutions. PR is more than just forming the desired institutional image, but also carrying out the function of public services. As emphasized in excellence theory, professional public relations focuses on achieving success between the organizations represented by the public relations and the community served (Cutlip, Center, \& Broom, 2011).

Government efforts to achieve the implementation of good information disclosure require optimal performance from public bodies. Suharyanti, et al., (2012) argued that the existence of the Law on Public Information Openness requires the government's role in opening access channels for communication with the public. This is reinforced by the opinion of Mendel (2004) that opening access to information is an obligation of the government and public bodies. Rayudaswati (2015) also mentioned that the open concept in transparency practices is also related to the role of public relations that can help the success of the transparency process.

The relationship between transparency and the role of public relations is proven by the research conducted by Wakefield \& Walton (2010) about the importance of communication and the role of public relations in transparency practices. The results of the study stated that organizations in any situation must maintain communication, one form of communication that is done is to do transparency and open access to public information. In the process of transparency, public relations practices must be carried out in order to maintain 
two-way communication (Wakefield \& Walton, 2010).

Edes (2000) mentions that the implementation of government policies requires the role of Public Relations practitioners, who are responsible for sharing more transparent government information on public affairs and information. Edes's opinion (2000) states that the role of government public relations is to safeguard public information, increase public policy awareness and public relations efforts in creating public awareness about government policy, facilitate feedback and two-way communication with the public, and use that information to improve the performance of institutions and accountability.

Research on the role of government public relations in the practice of transparency was conducted by Fairbanks, et al., (2007) using quantitative methods. Research conducted by Fairbanks et al. (2007) examines the development of a government public relations transparency model based on the value of transparency, organizational support, communication practices and the provision of resources. The results showed that organizational support is an important public relations factor in implementing transparency. Organizational support means that public relations has an administrative and management function in the practice of transparency (Fairbanks, et al, 2007). Public relations in the practice of transparency must have good communication internally to get organizational support, because organizational support is an important factor in realizing organizational goals.
Similar research on the important role of government public relations in the practice of transparency was also carried out by Oswald (2009). The purpose of this research is to find out whether the government in America in conducting transparency practices is guided by the transparency model. Based on previous findings, it is evidence that the use of the transparency dimension model is required by public relations in the practice of transparency. The practice of using these three dimensions of transparency is not only in the city level government but also in all government institutions (Oswald, 2009). Oswald's (2009) research shows that government public relations practitioners tend to be closed to the public when a scandal occurs, even though the role of public relations practitioners are to prevent a scandal in urban governance in America. The existence of the scandal has reduced public trust in the government, so this can damage the government's relationship with the community. The results of the study show that American city administrators that run the three dimensions of transparency will tend to be more open to the public, based on research on the transparency model used by American municipalities, namely the provision of resources, information practices, and organizational support (Oswald, 2009).

Public relations studies are dominated by the theory of excellence, making this theory the most influential theory in public relations research in the world (Gower, 2006; Pasadeos, Berger, \& Renfro, 2010). The theory of excellence is valued as a normative theory, namely as a standard measure of effective public relations (Bowen, Rawlins, \& Martin, 
2010; Cameron, Cropp, \& Reber, 2001; Fawkes, 2004; Harrison, 2009; Kent \& Taylor, 2007; Kriyantono, 2017), namely contributing as a management function to organizational effectiveness: building relationships and organizational conflict resolution (Bowen, Rawlins, \& Martin, 2010; Rhee, 2004).

Based on the description of the literature above about the relationship of democracy and public relations of higher education, the problem formulated by researchers is that the public relations activities of state universities as part of government institutions have met good standards. The standard used is according to the principle of excellence theory. These principles are public relations: strategic management functions (involvement); dominant coalition part and directly communicate with top management (empowerment); integrated into one department itself (integration); a management function that is separate from other management functions (independence); must carry out the function of the communication manager not just the communication technician (managerial); symmetrical twoway in establishing public relations (symmetrical model); internal communication systems are symmetrical two-way (symmetrical internal communication); the public relations function is carried out based on knowledge; the diversity of roles in carrying out functions (role diversity); and public relations must prioritize the code of ethics and professional integrity (ethical public relations) (Grunig, Grunig, \& Dozier, 2002).

\section{RESEARCH METHODS}

The Researcher used survey methods. The questionnaire was arranged based on ten principles of Excellent Theory to evaluate the effectiveness of public relations activities in tertiary institutions. The principles are as follows (Bowen \& Rawlins, 2010; Grunig et al. 2008; Kriyantono 2017):

Involvement of Public Relations in the strategic management function. Public relations must be involved in the management process to contribute to the organization. First, Public Relations must be part of the overall strategic management of the organization. Second, to contribute to overall strategic management, Public Relations must be able to design and manage management programs. The involvement of PR in the strategic management function also enables more objective decision making.

Empowerment of Public Relations in the dominant coalition

The Head of Public Relations must have direct access to communicate into the dominant group. The PR function must be empowered to report directly to the leadership. The report seems to suggest things that involve the public, values, and ethical decision making. To be involved or have access to the dominant coalition, public relations practitioners must improve their abilities through education, experience and professionalism. Integrated PR function.

The organization must have a Public Relations function integrated into its own department. Don't let each department have their own PR 
division. The integrated PR function has access and authority at all levels and functions of the organization. This means that the PR function is not isolated, but is not mixed with marketing functions or other functions. But has its own autonomy.

$\mathrm{PR}$ as a management function is separate from other functions or independent.

It is important for the PR unit to be part of a management function that is separate from other organizational management functions such as marketing, human resources development, or finance. This aims to prevent mixing with other management into the roles and responsibilities of management communication. When the public relations authority is mixed and limited by other organizational functions, the possibility is that the public is neglected in making organizational decisions.

Public Relations units or departments are led by a manager not a technician.

The PR unit must be led by a professional PR manager, not someone who is technically proficient in writing skills. Managers have the knowledge of the research needed to gather information, facilitate conflict resolution, engage in management issues, budget, and manage department staff. Without a manager who is responsible for the PR function, it is likely that the PR function will be isolated only to the extent of relations with the media rather than as a proper management function. A professional PR practitioner must have expertise in carrying out three managerial roles: Expert Prescriber; Communication Facilitator; Problem Solving Facilitator.

Adopt a symmetrical two-way PR model between an organization and its public.

Adopting a two-way symmetric model in organizations is important for a good public relations department. The results showed that a good PR department was the one who adopted the two-way symmetric model in its communication process, compared to the other three models, namely press agent, public information, and the two-way asymmetric model. In the application of a two-way or symmetrical model, a communication process balance can be achieved, because the relationship between the organization and the public is formed through negotiation and compromise.

Public Relations practitioners have knowledge of the PR field (knowledgeable).

A good PR department has members who are knowledgeable about PR (Knowledgeable). Knowledge of $\mathrm{PR}$ is needed to manage relations with the public, conduct analysis and engage in negotiations and problem solving.

Implement a symmetrical internal communication system. 
The results showed that one of the characteristics of an effective organization is implementing an internal communication system in two directions. By implementing a two-way, or symmetrical, internal communication system, employee satisfaction will be achieved. In addition, a symmetrical internal communication system can also build good relationships with employees, build trust with employees, and foster a participatory culture among employees. A symmetrical internal communication system also allows for exchanging or sharing information between employees, so that employee opinions can be accommodated in organizational decision making, respecting diversity in the organization.

The population in this study are practitioners who become heads of the technical division / sub-sections / units of Public Relations (UPT) of higher education institutions in Indonesia. Researchers distributed questionnaires during a workshop at the Ministry of Research and Technology and Higher Education which was inviting practitioners of higher education PR. The workshop was conducted in July 2018. There were 59 people who were willing to fill out the questionnaire. Data from the questionnaire were then analyzed descriptively to determine the average value of the quality of higher education PR activities based on this theory of excellence.

The research also conducted interviews with some public relations practitioners. There were three practitioners who were interviewed, namely public relations practitioners of Brawijaya University, Malang State University, and Malang State Islamic University. Interviews were conducted to complete the questionnaire data

\section{RESULTS AND DISCUSSIONS}

The data show that public relations activities in Indonesia have been good in the involvement of strategic management. This is seen from the results of the questionnaire that have been given that public relations practitioners have followed the leadership meeting to make strategic organizational decisions, public relations participated in designing and organizing the organization's strategic programs, public relations practitioners are also satisfied with their involvement in the organization's decision making process. It can be seen in the following Table 1:

Table 1. Involvement in Strategic Management

\begin{tabular}{|c|c|c|c|c|c|c|c|}
\hline \multicolumn{2}{|r|}{ Indicators } & \multicolumn{5}{|c|}{ Statements } & \multirow{2}{*}{$\begin{array}{l}\text { Mean } \\
\text { scores }\end{array}$} \\
\hline & & SA & A & $\mathrm{N}$ & NA & SNA & \\
\hline 1. & $\begin{array}{l}\text { I joined the leadership meeting } \\
\text { to make strategic organizational } \\
\text { decisions }\end{array}$ & 21 & 31 & 3 & 4 & 0 & 4.1 \\
\hline 2. & $\begin{array}{l}\text { I co-designed and managed the } \\
\text { organization's strategic program }\end{array}$ & 8 & 40 & 7 & 4 & 0 & 3.8 \\
\hline 3. & $\begin{array}{l}\text { I am satisfied with my } \\
\text { involvement in the } \\
\text { organizational decision-making } \\
\text { process }\end{array}$ & 8 & 40 & 7 & 3 & 1 & 3.8 \\
\hline
\end{tabular}


Of the three questions that have been given, public relations participation in leadership meetings for strategic organizational decision making is good. This can be seen from the average value in the first sub-point showing the value 4.1. In the second point, public relations involved in designing and organizing an organization's strategic program is still unknown. This can be seen from the second point which shows an average value of 3.8. The last point is the practitioners' satisfaction with involvement in the organizational decision making process, public relations tend not to know in this involvement process. It can be seen from the data above that the average value produced is 3.8. Based on the results of the category of level of agreed public relations in the involvement of strategic management is still not known, because the average value of the three points that indicate the involvement of strategic management is still 3.9.

The involvement of public relations in the strategic management function also allows for more objective decision making. PR itself is a storefront of an agency, it is meant that the ideal public relations should be able to see in its entirety what is happening within the scope of the agency. This is in accordance with interviews conducted by the researcher with Public Relations from Brawijaya University, he stated that:

"It means that as public relations of UB is also storefront. The ideal public relations practitioners view that public relations can see the overall university of Brawijaya. So they build imagery, build branding of the institution is indeed in public relations is ideally."

Public relations empowerment in the dominant coalition is good. The Head of Public Relations must have direct access to communicate into the dominant group (Kriyantono, 2017). The PR function must be empowered to report directly to the leadership. The report includes suggesting things that involve the public, values, and ethical decision making (Bowen \& Rawlins, 2010). To be able to have access to the dominant coalition, public relations practitioners must improve their abilities through education, experience and professionalism (Grunig et al 2008). It can be seen in Table 2 .

Related to the position of public relations in the institutional structure, the theory of excellence (L. A. Grunig, et al, 2002) explains that public relations is effective if (a) public relations has its own part, that is, not combined with other divisions / sections, even subordinated by other divisions; (b) the public relations part belongs to the upper structure (dominant coalition); (c) public relations is involved in decision making in dominant coalition. PR is effective if it is able to carry out its functions properly and this function is achieved if the PR is in the upper structure (dominant coalition). Opportunities to be involved in decisionmaking meetings and have direct access to leaders will be great if the practitioners are in that position (L.A. Grunig, et al, 2008; Kriyantono, 2017). 
Table 2. Public Relations Empowerment in the dominant coalition

\begin{tabular}{|c|c|c|c|c|c|c|c|}
\hline \multicolumn{2}{|c|}{ Indicators } & \multicolumn{5}{|c|}{ Statements } & \multirow{3}{*}{$\begin{array}{c}\text { Mean-scores } \\
4.3\end{array}$} \\
\hline & & \multirow{2}{*}{$\begin{array}{l}\text { SS } \\
26\end{array}$} & \multirow{2}{*}{$\begin{array}{c}\mathrm{S} \\
29\end{array}$} & \multirow{2}{*}{$\begin{array}{c}\text { TT } \\
1\end{array}$} & \multirow{2}{*}{$\begin{array}{c}\text { TS } \\
3\end{array}$} & \multirow{2}{*}{$\begin{array}{c}\text { STS } \\
0\end{array}$} & \\
\hline 1. & $\begin{array}{l}\text { I was given the opportunity to } \\
\text { express my suggestions directly } \\
\text { to the highest leadership in my } \\
\text { organization, related to the } \\
\text { communication function between } \\
\text { the organization and the public }\end{array}$ & & & & & & \\
\hline 2. & $\begin{array}{l}\text { I was given the opportunity to } \\
\text { submit suggestions directly to } \\
\text { other leaders (at top management } \\
\text { level), related to the } \\
\text { communication function between } \\
\text { the organization and the public }\end{array}$ & 24 & 34 & 0 & 1 & 0 & 4.3 \\
\hline 3. & $\begin{array}{l}\text { I plan and evaluate programs to } \\
\text { communicate with the internal } \\
\text { public }\end{array}$ & 18 & 34 & 4 & 3 & 0 & 4.1 \\
\hline 4. & $\begin{array}{l}\text { I plan and evaluate programs to } \\
\text { communicate with the external } \\
\text { public }\end{array}$ & 14 & 41 & 3 & 1 & 0 & 4.1 \\
\hline 5. & $\begin{array}{l}\text { I have the authority to access } \\
\text { information to all lines of the } \\
\text { organization }\end{array}$ & 17 & 30 & 4 & 8 & 0 & 3.9 \\
\hline
\end{tabular}

\section{Mean-scores}

Questionnaire data also shows that public relations is given the opportunity to submit suggestions directly to the highest leadership in the organization related to the communication function between the organization and the public related to the communication function between the organization and the public and public relations is given the opportunity to submit suggestions directly to other leaders (in top management level), it is good because it is seen from the average value of 4.3 which means that of the 59 interviewees have agreed with the sentence.

The PR from Islamic University of Malang (UIN) has a position equivalent to the Fourth Vice Chancellor. This is because from the beginning, the PR at UIN was not structurally held, so held by the lecturer himself. The relationship formed partnerships so that acceleration occurs in communication. This is consistent with what was conveyed by Mr. Sutaman in an interview on September 19, 2019, he said that:

"The public relations of the UIN has not been structurally held since the beginning, I am the third public relations officer, the first is Sudiyono, Fanani and my third, and the fourth now is the same. So the relationship between the lecturer and the partner is a partnership, so I can joke with the chancellor, because I am a lecturer seconded to public relations. Because what is desired is the speed of communication."

This is almost the same as the third and fourth points which show an average value of 4.1. PR has agreed with the third and fourth points given by researchers that 
public relations plans and evaluates programs to communicate with internal public and plans and evaluates programs to communicate with external public. Another case with the fifth or final point, that public relations does not know about the given sub points, namely that public relations has the authority to access information to all lines of the organization. Based on these results shows that the level of public relations agreed in the empowerment of the dominant coalition is good, it can be seen from the overall average of the five points given the average value of 4.1 .

Table 3 shows data about integrated PR functions and management functions separate from other or independent functions. Organizations must have a Public Relations function integrated into their own department (Cutlip, Center, \& Broom, 2011; Kriyantono, 2017). The integrated PR function has access and authority at all levels and functions of the organization so that the PR function is not isolated, but is not mixed with marketing functions or other functions (Bowen \& Rawlins, 2010). Public relations must also integrate all information in one communication channel, including communication through the website (Searson \& Johnson, 2010), known as digital public relations (Vercic, Vercic, \& Sriramesh, 2015).

It is important for the PR unit to be part of a management function that is separate from other organizational management functions such as marketing, human resources development, or finance (Kriyantono, 2017). This aims to prevent mixing with other management into the roles and responsibilities of communication management (Parthawa, Kriyantono, \& Wisadirana, 2015). When the public relations authority is mixed and limited by other organizational functions, then what is likely to happen is the public's neglect in organizational decision making (Lattimore et al. 2013).

Table 3. Integrated and independent PR

\begin{tabular}{|c|c|c|c|c|c|c|c|}
\hline \multicolumn{2}{|c|}{ Indicators } & \multicolumn{5}{|c|}{ Statements } & \multirow{3}{*}{$\begin{array}{l}\text { Mean- } \\
\text { scores } \\
4.2\end{array}$} \\
\hline & & \multirow{2}{*}{ SS } & \multirow{2}{*}{$\begin{array}{l}\mathrm{S} \\
39\end{array}$} & \multirow{2}{*}{$\begin{array}{l}\mathrm{TT} \\
1\end{array}$} & \multirow{2}{*}{$\begin{array}{l}\text { TS } \\
1\end{array}$} & \multirow{2}{*}{$\begin{array}{l}\text { STS } \\
0\end{array}$} & \\
\hline 1. & $\begin{array}{l}\text { I have the authority to work with other } \\
\text { divisions }\end{array}$ & & & & & & \\
\hline 2. & $\begin{array}{l}\text { The organization has its own } \\
\text { department/division/bureau/Public } \\
\text { Relations department }\end{array}$ & 28 & 21 & 4 & 5 & 1 & 4.1 \\
\hline 3. & $\begin{array}{l}\text { The PR Division stands alone \& is not } \\
\text { under another division. For example, the } \\
\text { public relations department is in the } \\
\text { marketing section }\end{array}$ & 25 & 19 & 4 & 8 & 3 & 3.9 \\
\hline
\end{tabular}

Mean-score

Based on the data above, it can be seen from the three sub-questions that have been given in the first point that public relations has the authority to work with other divisions showing an average value of 4.2 or agree. On the second point, the average result of 4.1 also shows that public relations has its own part. Based on these results, if the three sub-categories are averaged, it will get a mean of 4.0 , which indicates that the respondents agrees that the public relations management function 
must be separate from other functions or independent.

The PR unit must be led by a professional PR manager, not someone who is technically proficient in writing skills (Lattimore et al. 2013). Managers have the knowledge of the research needed to gather information, facilitate conflict resolution, engage in management issues, make budgets, and to manage the staff of the Public Relations department (Bowen \& Rawlins, 2010). Without a manager who is responsible for the PR function, it is likely that the PR function will be isolated only to the extent of relations with the media rather than as a proper management function (Motion \& Leitch, 2015). A professional PR practitioner must have expertise in carrying out three managerial roles: Expert Prescriber, Communication Facilitator, Problem Solving Facilitator (Cutlip, Center \& Broom, 2011).

The public relations department must be led by someone who is a professional in the field of public relations, not only technically proficient or just an expert writing. A public relations leader must have the research knowledge needed to gather various information, facilitate conflict resolution, engage in management issues, budget, and manage department staff. Expertise in becoming a public relations leader is also owned by the Malang City Government. One of the public relations staff of the Malang City Government in an interview conducted on 19 September 2019 explained that:

"I experienced from some of these sections that for this Mr. Nurwidiyanto the issue management was very shrewd compared to the previous Kabag. There are so many sections that fail in managing this management, because sometimes management of the issue is necessary if the leader will be entangled everywhere."

The ability of public relations practitioners can be grouped into two, namely the managerial ability of communication and the ability of communication technicians. Managerial ability is the ability to identify issues and problems (expert prescriber), mediators or facilitate mutual two-way communication between institutions and the public (communication facilitators), and problem solving facilitators, which help leaders solve problems and oversee the implementation of problem solving (Kriyantono, 2014a ; LA Grunig, et al, 2002; Lattimore, et al, 2007; Perthawa, Kriyantono, \& Wisadirana, 2015). Communication technician ability, is the ability in communication techniques such as writing press releases, writing speech texts, public speaking or graphic design (Kriyantono, 2017; Grunig, et al, 2008; Lattimore, et al, 2007). According to the theory of excellence, the greater the public relations opportunity is in the upper structure position, involved in decision making, and gaining direct access, the greater the public relations opportunity is doing managerial tasks. In other words, managerial tasks are the demands that must be carried out by public relations if the public relations wants to be in a position of upper structure and involved in decision making in institutions (Grunig, 2008; Kriyantono, 2017; Lattimore, et al, 2013). It can be seen in Table 4.

Table 4. Managerial roles

\begin{tabular}{lll}
\hline Indicators & Statements & Mean-scores
\end{tabular}




\begin{tabular}{|c|c|c|c|c|c|c|c|}
\hline & & SS & $\mathrm{S}$ & TT & TS & STS & \\
\hline 1. & $\begin{array}{l}\text { I identify problems (issues) that } \\
\text { are happening and identify } \\
\text { potential problems with the } \\
\text { organization }\end{array}$ & 8 & 44 & 4 & 3 & 0 & 3.9 \\
\hline 2. & $\begin{array}{l}\text { I provide solutions to problems } \\
\text { with the leadership, such as by } \\
\text { offering a program to overcome } \\
\text { the problem (issue) }\end{array}$ & 9 & 45 & 3 & 2 & 0 & 4.0 \\
\hline 3. & $\begin{array}{l}\text { I participated in implementing } \\
\text { the program (on number 2) }\end{array}$ & 8 & 42 & 5 & 4 & 0 & 3.9 \\
\hline & Mean-scores & 3.9 & & & & & \\
\hline
\end{tabular}

Based on the data above, it can be seen from the three questions that have been given in the first and third points that have the same average results, namely 3.9. Public relations practitioners do not know about public relations to identify problems (issues) that are happening and identify potential problems that occur in the organization and implement the program in handling issues. Whereas the sub-PR questions provide solutions to the leadership problems, such as by offering programs to solve problems (issues) showing an average value of 4.0, which means that public relations agrees in handling the issue. These results indicate that public relations still does not know about handling issues and the public relations unit must be led by a professional PR manager, this is because the average value at this sub point still shows the number 3.9.

Adopting a two-way symmetric model in organizations is important for a good public relations department (Bowen \& Rawlins, 2010). The results show that a good PR department adopts a two-way symmetric model in its communication process, compared to the other three models, namely press agent, public information, and two-way asymmetric models (Grunig et al. 2008). In the application of a two-way or symmetrical model, a communication process balance can be achieved, because the relationship between the organization and the public is formed through negotiation and compromise (Syahri, Kriyantono, \& Nasution, 2015).

Without a responsible public relations leader, public relations will be isolated only to the extent of relations with the media rather than with its proper management function. So a public relations leader must be able to solve a problem. This was also done by the public relations officer of UIN Malang, he conducted several stages to solve the existing problems. Based on data that researchers obtained through interviews on September 19, 2019, public relations from UIN Malang explained that:

"For issue management, since the crisis in UIN requires that there is an issue management, even turning or turning the issue, not covering it but deflecting the issue. It is still in the management of the settlement. Management of settlement is using jagongan. That's the language like that if my legal consultant uses formal wear. Later, if you wear it formally for a 
year, two years, a long time, sometimes even three years. "

Some practitioners also admit that they are conducting technical roles. Public Relation has duties in each institution, such as to do coverage, reporting, writing, and publication. Public Relations practitioners has the authority to regulate the website in an agency. Public Relations will form relationships with various media, this aims to make news externally. PR also has a duty to compare an agency, both in online and offline media. In an interview conducted on 19 September 2019, public relations from Malang State University stated that he manages the web. The web is in the news section, managing Twitter, online clippings, that is managing PR.

The results showed that one of the characteristics of an effective organization is implementing an internal communication system in two directions.

By implementing a two-way, or symmetrical, internal communication system, employee satisfaction will be achieved. In addition, a symmetrical internal communication system can also build good relationships with employees, build trust with employees, and foster a participatory culture among employees. Symmetrical internal communication systems also allow for exchanging or sharing information between employees, so that employee opinions can be accommodated in organizational decision making (Grunig, 2008).

The following data is conducted by researchers with 59 people about how to adopt a symmetrical two-way public relations model between organizations and their public and the application of a symmetrical internal communication system:

Table 5. Symmetrical PR

\begin{tabular}{|c|c|c|c|c|c|c|c|}
\hline \multicolumn{2}{|c|}{ Indicators } & \multicolumn{5}{|c|}{ Statements } & \multirow{3}{*}{$\begin{array}{l}\text { Mean-scores } \\
3.7\end{array}$} \\
\hline & & \multirow{2}{*}{$\begin{array}{l}\text { SS } \\
8\end{array}$} & \multirow{2}{*}{$\begin{array}{l}\mathrm{S} \\
38\end{array}$} & \multirow{2}{*}{$\begin{array}{l}\text { TT } \\
6\end{array}$} & \multirow{2}{*}{$\begin{array}{l}\text { TS } \\
6\end{array}$} & \multirow{2}{*}{$\begin{array}{l}\text { STS } \\
1\end{array}$} & \\
\hline 1. & $\begin{array}{l}\text { I am the mediator of } \\
\text { communication between the } \\
\text { organization and the internal } \\
\text { public (such as employees) }\end{array}$ & & & & & & \\
\hline 2. & $\begin{array}{l}\text { I am the mediator of } \\
\text { communication between the } \\
\text { organization and the external } \\
\text { public (such as the media and the } \\
\text { public }\end{array}$ & 18 & 31 & 7 & 2 & 1 & 4.0 \\
\hline 3. & $\begin{array}{l}\text { I provide communication } \\
\text { channels in various forms so that } \\
\text { the internal public can provide } \\
\text { feedback (such as complaints, } \\
\text { criticisms, suggestions) to the } \\
\text { organization }\end{array}$ & 16 & 30 & 9 & 3 & 1 & 3.9 \\
\hline 4. & $\begin{array}{l}\text { I provide communication } \\
\text { channels in various forms so that } \\
\text { the external public can provide } \\
\text { feedback (such as complaints, } \\
\text { criticisms, suggestions) to the }\end{array}$ & 16 & 34 & 8 & 1 & 0 & 4.1 \\
\hline
\end{tabular}




\begin{tabular}{|c|c|c|c|c|c|c|c|}
\hline & organization & & & & & & \\
\hline 5. & $\begin{array}{l}\text { I respond to and follow up on } \\
\text { feedback provided by the internal } \\
\text { public, including following up } \\
\text { with other relevant leaders and } \\
\text { divisions }\end{array}$ & 11 & 39 & 5 & 3 & 1 & 3.9 \\
\hline 6. & $\begin{array}{l}\text { I respond and follow up on the } \\
\text { feedback given by the external } \\
\text { public, including following up } \\
\text { with other relevant leaders and } \\
\text { divisions }\end{array}$ & 11 & 43 & 1 & 3 & 1 & 4.0 \\
\hline 7. & $\begin{array}{l}\text { I negotiate with internal \& } \\
\text { external public to reach an } \\
\text { agreement }\end{array}$ & 7 & 33 & 10 & 7 & 2 & 3.6 \\
\hline \multirow[t]{2}{*}{8.} & $\begin{array}{l}\text { I created a dialogical internal } \\
\text { communication system to build } \\
\text { cooperation, increase morale and } \\
\text { work satisfaction of all } \\
\text { employees in my organization }\end{array}$ & 5 & 37 & 12 & 4 & 1 & 3.9 \\
\hline & Mean-scores & 3.8 & & & & & \\
\hline
\end{tabular}

Based on data that researchers conducted with 59 people about how the adoption of a symmetrical two-way PR model between organizations and their public and the application of a symmetrical internal communication system was obtained that in the first sub point namely public relations being the mediator of communication between organizations and internal public (such as employees) still shows an average value of 3.7 which means don't know. The average value of 3.1-3.9 which shows the ignorance of public relations is also found in the question points $3,5,7$, and 8 , each showing an average value of 3.9, 3.9, 3.6, and 3.9. This explains that public relations still does not know that public relations provides communication channels in various forms so that the internal public can provide feedback (such as complaints, criticisms, suggestions) to the organization, public relations also do not know how to respond and follow up on feedback provided by the internal public, including following up on leaders and other related divisions, public relations do not know how to negotiate with internal \& external public to reach an agreement and public relations do not know how to create a dialogical internal communication system to build cooperation, improve morale and work satisfaction of all employees in his organization.

Unlike the case with question points number 2, 4, and 6. The average value of each of these points shows the numbers 4.0, 4.1, and 4.0. This shows that public relations has agreed that public relations becomes a mediator of communication between organizations and external public (such as media and society, public relations also agrees that public relations provides communication channels in various forms so that external public can provide feedback (such as complaints, criticisms, suggestions) to the organization and public relations respond 
to and follow up on feedback provided by the external public, including following up with the leaders and other relevant divisions.

The findings of this data explain that public relations as a communication governance activity is directed to internal and external public. Based on literature, such as Cutlip, et al (2011); Grunig \& Hunt (1984); Lattimore, et al (2013), public relations has two publics, namely internal public, such as employees and leaders, and external public, such as mass media, consumers or other stakeholders. Media is a very important external public. The media needs public relations to obtain effective, efficient, interesting and informative news material for the public while public relations requires journalists as audiences, mediators and gatekeepers to convey information and respond to the public's need to know and public relations has the task of building a positive image (Kriyantono, 2015; Lattimore et al. 2013). "Media relations are important programs conducted by public relations practitioners. The reason will be that PR needs a communication process to make relations that they can obtain their goals to develop, guide, and keep a positive image or good reputation. "(Syahri, Kriyantono, \& Nasution, 2015, h. 36).

\section{CONCLUSION}

In general, in this era of public information disclosure, public relations activities in state tertiary institutions which are the object of study can be said to be good, with a two-way communication system with internal public and mass media. It can be concluded that if public relations is in a high structural position, public relations tends to perform managerial tasks. To be involved in decision making and direct access to the highest leadership, public relations does not have to be in a high structural position. Managerial ability is increasingly felt in public relations which has its own part. There is no difference between the main targets between public relations managers who are more tasked with managerial communication technicians. The biggest problem of communication governance in higher education institutions is the low role of the leadership.

Research on public relations activities at public universities in the era of public information disclosure has found that public relations activities have well supported public services in accordance with the principles of good governance. Public relations practitioners has applied the principles of excellent theory well including the involvement of public relations in the strategic management function, public relations has been empowered in a dominant coalition, an integrated public relations function, public relations has also been independent in the department, led by practitioners who are experts, applying symmetrical two-way models, has knowledge of public relations, respects diversity in an organization and public relations has followed the code of ethics and has the integrity of the profession in public relations practice.

For future research, the researcher recommend conducting survey research to evaluate the effectiveness of Public Relations activities by examining intercategory influences in this theory of excellence. In addition, qualitative research needs to be carried out to explore in depth how the public relations programs 
of state universities are implemented in building effective communication systems.

\section{ACKNOWLEGEMENT}

The author thank to Brawijaya University for the support of the research and publication.

\section{REFERENCES}

Akanwa, P. C., Anyanwu, E. U, Ossai-Onah, O. V. (2013). Population control in Nigeria: Implications for librarians. Retrieved from https://www.questia.com/read/1P33879700741/population-control-innigeria-implications-for-librarians

Bowen, S. A., Rawlins, B., \& Martin, T. (2010). Best practice for excellence in public relations from overview of the public relations function. Harvard: Harvard Business Publishing.

Cameron, G.T., Cropp, F., \& Reber, B.H. (2001). Getting Past Platitudes: Factors Limiting Accomodation in

Public Relations. Journal of Communication Management, 5 (3), 242-261.

Cutlip, S., Center, A., \& Broom, G. (2011). Effective Public Relations. Jakarta: Kencana Prenada Media Group.

Dikopoulo. A., \& Athanassions Mihiosis. 2013. The Contribution of records management to good governance. TQM Journal, 24(2), 123-141.

Edes. B.W. (2000). The role of public administration in providing information information offices \& citizens information services. Presentation at the EIPA Seminar on "An Efficient, Transparent Government and the Rights of Citizens to Information". Netherlands

Fairbank, J., Plowman, K. D., \& Rawlins, B. L. (2007). Transparency and city government communication. Journal of Public Affair, 7, 23-27.

Fawkes, J. (2004). What is Public Relations. In A. Theaker (Ed.), The Public
Relations Handbook. New York: Routledge.

Gower, K. K. (2006). Public Relations Research at The Crossroads. Journal of Public Relations Research, 18(2), 177-190.

Grunig, L. A., Grunig, J. E., \& Dozier, D. M. (Eds.). (2008). Excellence public relations and effective organization. New Jersey: Lawrence Erlbaum.

Grunig, J. E., \& Hunt, T. (1984). Managing Public Relations. New York: Rinehart \& Winston.

Harrison, K. (2009). Strategic Public Relations: A Practical Guide to Success. Perth: Century.

Kent, M. L., \& Taylor, M. (2007). Beyond Excellence: Extending The Generic Approach to International Public Relations The Case of Bosnia. Public Relations Review, 33, 10-20.

Kriyantono, R., Destrity, N. A., Amrullah, A., \& Rakhmawati, F. (2017). Management of public relations for supporting the anti-corruption national program in Indonesia. International Journal of Applied Business and Economic Research, 15(20), 293-303.

Kriyantono, R. (2017). Teori public relations perspektif barat dan local: Aplikasi penelitian dan praktis. Jakarta: Prenada.

Kriyantono, R. (2015). Public relations, issue, \& crisis management. Jakarta: Prenada.

Lattimore, D., Baskin, O., Heiman, S., \& Toth, E. L. (2013). Public Relations: The Profession and The Practice. New York: McGraw-Hill.

Mendel, T. (2012). Freedom of information as an internationally protected human right. Retrieved from http://ww.article19.0rg/pdfs/publication s/fori-as-an-international-right.pdf, in 2 October 2015

Motion, J. \& Leitch, S. (2000). The truth games of public relations politics. 
Australian

Journal

of

Communications, 27(2), 65-80.

Ohemeng, F. L. K., \& Adarkwa, K. (2014).

Overcoming the digital divide in developing countries: An examination of Ghana's strategies to promote universal access to information communication technologies (ICTs), Journal of Developing Societies, 30(3), 297-322.

Oswald.J. (2009). Transparency and city government communications. All Theses and Dissertations. Brigham Young University.

Parthawa, P.B., Kriyantono, R., \& Wisadirana. (2015). A Test of Five-Factor Model on Different Roles of Government and Private Public Relations Practitioners in Indonesia. Global Journal of HumanSocial Science, 15(4), 17-22.

Pasadeos, Y., Berger, B., \& Renfro, R. B. (2010). Public Relations as a Maturing Discipline: An Update on Research Networks. Journal of Public Relations Research, 22(2), 136-158.

Prabowo, R.D. (2014). Implementasi undangundang keterbukaan informasi publik dalam upaya mewujudkan good governance (kajian tiga badan publik: Bappeda, Dpkad Dan Dinas Pendidikan Kota Semarang). Universitas Diponegoro.

Pradipta, H. (2013). Keterbukaan informasi publik Di Jawa Timur (Studi kasus sengketa informasi publik). Universitas Brawijaya : Malang.

Purdy, A. C., Idriss, A., Ahern, S., Lin, E., Elfenbein, D. M. (2017). The readability and accuracy of patient education websites for Graves' disease treatment. Surgery, 162(5), 1148- 1154.

Rayudaswati. (2015). Public information management service in south sulawesi. Journal of Public Administration, 13(14), 1-12.

Retnowati, E. (2012). Keterbukaan informasi publik dan good governance (antara das sein dan das sollen). Jurnal Perspektif, 27 (1), 55-60.

Schenkeelar, F., \& Ahmad, I. (2004). Transparency and accountability in the public sector in the arab region. Paper for access to information, transparency and accountability, 1(6), 1-16.

Searson, E. M., \& Johnson, M. A. (2010). Transparency laws and interactive public relations: An analysis of latin american government websites. Public Relation Review, 36, 120126.

Suharyanti,. Widiastuti., Kania. (2012).Reformasi birokrasi pemerintah dan penerapan excellence theory. Jurnal Ilmu Komunikasi, 10(1), 53-63.

Syahri, M. A., Kriyantono, R. \& Nasution, Z. (2015). An Explanative Study on The Different Perceptions of Journalists Toward Media Relations of Governmental and Private Public. Asian Journal of Humanities \& Social Sciences, 3(1), 36-48.

Vercic, D., Vercic, A. T., \& Sriramesh K. (2015). Looking for digital in public relations. Journal of Public Relations Review, 41, 142-152.

Wakefield, R.I., \& Walton, S, I. (2010). The translucency corollary: Why full transparency is not always the most ethical approach. Public Relations Journal, 4 (4), 10-23.

Wijayanti, S. (2018). 10 Ciri Dasar Generasi Millennial, Kamu Termasuk Gak Nih? Retrieve from https://www.idntimes.com/life/inspirat ion/sinta-wijayanti- $\quad \mathrm{d} / 10$-ciri-dasargenerasi-millennial-c1c2/full. 